\title{
Malaysia's Proactive Economic Zone Regime as a Model to Emulate for Success of Bangladesh Economic Zone Scheme
}

\author{
Md. Mahmudul Alam* \\ National University of Malaysia (UKM), Malaysia \\ Email: rony000@gmail.com \\ Rafiqul Islam Molla \\ International Islamic University Chittagong, Bangladesh \\ Email: rimolla@gmail.com \\ Md. Wahid Murad \\ University of South Australia, Australia \\ Email: mwmurad@gmail.com \\ ${ }^{*}$ corresponding author
}

\section{Citation Reference:}

Alam, M.M., Molla, R.I., and Murad, M.W. 2014. Malaysia's Proactive Economic Zone Regime as a Model to Emulate for Success of Bangladesh Economic Zone Scheme, Journal of Developing Areas. Vol. 48(2), pp. 399-407. [Online Link]

This is a pre-publication copy.

The published article is copyrighted by the publisher of the journal. 
MALAYSIA'S PROACTIVE ECONOMIC ZONE REGIME AS A MODEL TO EMULATE FOR SUCCESS OF BANGLADESH ECONOMIC ZONE SCHEME

\author{
Md. Mahmudul Alam \\ National University of Malaysia (UKM), Malaysia \\ Rafiqul Islam Molla \\ International Islamic University Chittagong, Bangladesh \\ Md. Wahid Murad \\ University of South Australia, Australia
}

\begin{abstract}
Economic zone or export processing zone in a country is a purpose-built industrial park with infrastructure designed to suit the needs of foreign as well as local investors. In order to tempt foreign investors into the zones the host developing countries offer a variety of incentives. By encouraging and motivating the multinational companies to settle their Greenfield investments in developing countries, the economic zone scheme acts as a tool for empowering the local economy to gain multiple capabilities and go global increasingly to facilitate income convergence between the industrialized and the developing countries through equitable sharing of the gains from trade. Nonetheless, it is not a magic wand. Its experiences in Malaysia and Bangladesh clearly show that it can create wonder only when it is appropriately designed and managed. It is suggested that Bangladesh borrows a leaf from the rich experiences of Malaysia's economic zone model, to restructure and revitalize her economic zone scheme for greater success.
\end{abstract}

JEL Classification: F21, H87, J24, L52, O14, O25

Keywords: Economic zone, globalization, industrialization, Malaysia, Bangladesh

Corresponding Author's Email Address: rony000@gmail.com

\title{
INTRODUCTION
}

Industrialization is a phase of a country's economic development in which industries grow faster and gradually come to play the leading role in the economy. This necessitates pursuing an export oriented industrialization leading to economic globalization for free movement of both industrial outputs and inputs. Unfortunately, there are serious political and sociological problems for free movement of labor. At the same time movement of capital is highly limited because of investors' fear of insecurity of their investments in the host developing countries. However, compared to labor, movement of capital is relatively simpler, easier and more feasible. As a result, the scheme of Free Trade Zone or Export Processing Zone (EPZ) came as an innovative mechanism for motivating the capital owners in the industrialized countries to invest and establish plants (Greenfield investment) in the developing countries. It provides adequate incentives and security to foreign investments, but at the same time provide necessary guards against the inherent selfish motive of the multinational companies (MNCs) and protect the benefits of the host countries. In fact it acts like a scheme for guided globalization.

Economic zones in a country usually are purpose-built industrial parks with dedicated infrastructure designed to suit the needs of investors from foreign and host countries. These are named differently in different countries. Terms such as Export Processing Zone (EPZ), Free Trade Zone (FTZ), Special Economic Zone (SEZ), Free Port (FP), Enterprise Zone 
(EZ), Single Factory EPZ, Hybrid EPZ, Export Processing Factory (EPF), Specialized Zone, etc. refer to similar concepts with variations determined by policy prescriptions and objectives. It is termed as Free Trade Zone in Malaysia and Export Processing Zone in Bangladesh. These are primarily used as tools for economic globalization and export-led national economic growth, and increase in employment, exports, and foreign exchange earnings. Modern economic zones could be publicly owned or privately owned or jointly owned Public-Private Projects (PPP). These could be enclaves exclusive of the national economy or inclusive and integrated with the national economy. Integrated ones are preferable for national economic development.

Of the many nations that have used EPZ as a strategy for industrialization, Malaysia is among the most successful. It has done so well. It is the $29^{\text {th }}$ largest economy in the world. However, Bangladesh is no less endowed with resources and human capital compared to Malaysia. The two countries had the same background of colonial and agrarian economy. But the later has clearly broken away from the rank of the less developed nations to that of an emerging middle income nations on its way to becoming a fully developed economy. This contrasts with the modest success of Bangladesh. Therefore, a critical analysis of the performances of the economic zone regimes in the two countries will be very helpful to plan useful policy guidelines for Bangladesh EPZ scheme to be able to play its full potential role.

\section{MALAYSIA'S INDUSTRIALIZATION \& ECONOMIC ZONE REGIME}

Malaysia's industrialization and globalization approach is a strategy of growth with equity. It can be best described as a strong market embedded into a strong government and is driven by Malaysia's vision of becoming a fully developed and industrialized knowledge-based nation by the year 2020. It is a highly target oriented phase by phase approach strictly monitored and modified as necessary by compromising efficiency for effectiveness. Fostering national unity and growth with socio-economic justice through broader quantitative and qualitative participation of all groups of people at all levels of activities are the hardcore and touchstones of the approach and its tools and strategies. It is guided by long-term plans such as New Economic Policy, Outline Perspective Plans, National Development Policy, various Industrial and Knowledge based Master Plans, etc. It is pursued through medium-term operational plans such as five-year Malaysia plans. In 1991 Malaysia formally articulated her vision as a blueprint of national development over a period of thirty years under the name Vision 2020, to transform herself finally from a developing to a fully developed nation not only in economic sense but along all the dimensions: economic, political, social, spiritual, psychological, and cultural. The country projects per capita annual GDP to grow at the rate of $7-8 \%$ and expects annual GDP per capita to rise from $\$ 2,000$ to $\$ 17,000$. Accordingly, her level of globalization and level of industrial competitiveness have been on steady increase since 1970.

From a background of a colonial agrarian open economy, Malaysia formally started her industrialization journey in 1957 and proceeded phase by phase through the road map of development to realize her vision of becoming a 'fully developed' nation by 2020 . Her development pattern follows the stereo type that starts with the import-substitution based industrialization and ends with technology-intensive high-value adding industrialization. Industrialization and globalization of her economy effectively started from 1970 with the program of export oriented industrialization with the added program of industrial and social restructurings. Its scale increased steadily during 1970-2007. Recognizing the danger of the deceptive nature of capitalist globalization, Malaysia approached economic globalization very prudently through a strategy of export-oriented industrialization with internal and 
external investments, but without yielding to any pressure and influence of the dominant nations and international organizations. Distancing herself from the capitalist mould and upholding her own unique personality, Malaysia pursues an economic model that is known today as 'Malaysia model of economic development and globalization' with the 'look east' and 'Malaysia-centric' autonomous identity themes as the mastermind and hardcore, and the schemes of Free Trade Zones (FTZs) and Economic Development Corridors (EDCs) as the cornerstones of its pattern and structure. It is a dynamic approach providing for necessary modifications, extensions, and changes in strategies and actions at different phases of development. With these unique features her development model has become widely recognized as a 'Malaysia model of economic development and globalization for the developing nations'.

The structure and time-path of Malaysia's industrialization and globalization can be summarized from Cheng (2008) as follows:

(1) 1957-1969: Import substitution based industrialization - to encourage growth of domestic industries for producing simple consumer goods mainly for home consumption and increase in employment.

(2) 1970-1990: Outward looking industrialization and industrial and social restructuring to encourage increased foreign investment and transfer of technology in the country and to link the export oriented industries with the domestic sector of the economy. Targets were production for global market, increase in economic growth, eradication of poverty, and reduction in disparity of income levels, education and skill, economic functions, and employment opportunities among different ethnic groups. It passed through the following phases:

(i) 1970-1980: Growth of export-oriented light industries - creation of free trade zones (FTZs) to attract local and international investments and production for export.

(ii) 1980-1985: Growth of heavy industries - through establishment of some government pushed and supported heavy industries like automobile, steel, cement, and petrochemicals, under heavy protection from outside competition.

(iii) 1985-1990: Trade and investment liberalization - to bring structural adjustments in the industrial sector. Privatization was mooted to transform many government owned companies into government linked companies (GLC). Restriction on foreign equity was relaxed allowing foreign investors to be able to hold up to $100 \%$ of the equity.

(iv) 1991-2020: This is the phase of taking the economy to its full maturity, through rigorous tests of international competitiveness, and stepping into the state of affluence to mark the full realization of the vision of becoming a fully developed and industrialized knowledge-based country underscoring national unity and socio-economic justice.

\section{THE ECONOMIC ZONE REGIME}

This scheme, as a strategy for industrial development, started in 1970s. It was reformed and modernized in 1990 to make it more integrated with the national economy through backward and forward linkages of companies located in the zones. In recent years, it launched 4 large economic development zones in a bid to ensure a balanced development of the country.

\section{Structure of the Scheme}


Malaysia's economic zone regime includes Free Trade Zone (FTZ) and Economic Development Corridor (EDC). It refers to an area mainly designed to promote entrepot trade and for manufacturing industries producing goods for export.

(1) It is comprised of:

(i) Free commercial zone for commercial activities which include trading (except retailing), breaking bulk, grading, repacking, relabeling, transit, etc., and

(ii) Free industrial zone for manufacturing activities for all goods except the prohibited items.

(2) It is governed by Free Trade Zone Act 1971, Free Zones Act 1990 and Free Zone Regulations 1991. Each zone is administered by a Zone Authority appointed by the Ministry of Finance (PRU 2011). The Zone Authority for each FTZ is named differently.

(3) Starting in 1970s, it has now 11 operating FTZs (4 in Penang, 3 in Selangor, 2 in Johor states) and 2 Free ports (Labuan in the East Cost- for finance and insurance business, and Langkawi in the West Coast - for tourism industry).

(4) In addition, it has the recently launched following 4 large free economic zones /corridors (WTEC 1997, Lim and Hamid 2008):

(i) Iskandar Development Region (IDR), also called South Johor Economic Region (SJER). It is Malaysia's largest free economic zone. It expects to create 800,000 jobs, and attract $\$ 100$ billion investment over 25 years.

(ii) East Coast Economic Region (ECER). It is very large. It expects to create 560,000 jobs and attract $\$ 34$ billion investment over 12 years.

(iii) Northern Corridor Economic Region (NCER). It will be a logistics and transportation hub of the region. It will serve Indonesia-Malaysia-Thailand growth triangle.

(iv) Economic Region of Saba and Sarawak (ERSS) :

a. Sabah Development Corridor (SDC)

b. Sarawak Corridor of Renewable Energy (SCORE)

(5) To be placed in the zone a company must export at least $80 \%$ of its outputs.

\section{Special Attractions for Foreign Investors}

(1) Political stability and a state-of-the art industrial infrastructure, and, most essential of all, the security for investment.

(2) Most convenient geographic location with deep-water ports, modern sea and airports, transportation system, steady power and water supply, and other financial and institutional infrastructure.

(3) Continuous supply of low-cost industrial labor made available from the neighboring labor surplus ASEAN and South Asian countries.

(4) Investment friendly environment with fast custom and other services, tempting fiscal incentives, and easy foreign exchange control permitting full repatriation of capital and dividend (BERNAMA 2009).

(5) Minimum custom duty and income tax payment for a stipulated initial period.

(6) 30 to $100 \%$ foreign ownership for companies based on level of exports of their outputs and patent right for 15 years (US State Department 2011)

(7) Kuala Lumpur is a leading center for the growing Islamic financial market. Malaysia has been a magnet for Middle Eastern investors. 
Smartness of Malaysia's economic zone scheme lies in it's dynamism: a) commitment to protect the national interest as well as the interests of the enterprises housed in the zones, b) commitment to directing industrialization towards a balanced development of all parts of the country, and c) constantly accommodating to the changing circumstances along the processes and stages of industrialization and globalization. However, the political will, commitment, and stability, and a highly disciplined (uncorrupted) management can be said to be the most distinguishing feature of her free trade zone scheme.

\section{Achievements}

Despite the increasing global competition for receiving FDI, Malaysia continues to attract global foreign investment outflows. Economic Zone regime most successfully played the pivotal role in the export-led industrialization strategy. Success of Malaysia's industrialization and globalization can be largely attributed to the success of her economic zone scheme. It is the center of gravity of the FDI inflows. About $61 \%$ of the FDI inflows landed in the zones. It accounted for about $80 \%$ of national's merchandise exports (ILO 2003). It caused the diversification of Malaysia's exports. Since the opening up of the investment regime in 1985, the contribution of foreign establishments to total value-added of the manufacturing sector increased from $33.4 \%$ to $44.2 \%$ (during 1986 - 1999) and their employment share increased from $30.3 \%$ to $38.1 \%$ during the same period (Raquib et al. 2007). In 2006 FDI inflows contributed to almost a fifth of the country's annual Fixed Capital Formation.

Economic globalization in Malaysia increased steadily during 1970-2006. Index of globalization level increased from 63 in 1970 to 78 in 2006. Achievements of its development and globalization strategy can be evaluated from the context of national macroeconomic goals and global competitiveness and income convergence (benefits sharing) objectives. She had significant and commendable achievements in these respects. During 1970 - 2006 per capita real gross national income (GNI) increased from $\$ 1,110$ to $\$ 5,140$ with an average annual growth rate of $5 \%$. If it maintains $5.4 \%$ for the remaining period of 10 years per capita GDP will reach $\$ 15,300$ which is the minimum for a high income economy. Unemployment rate dropped from $8 \%$ in 1970 to $3.1 \%$ in 2008, inflation rate dropped from $4.49 \%$ in 1975 to $2 \%$ in 2007 (Cheng 2008), foreigners' share of equity capital decreased from $63.4 \%$ in 1970 to $28.8 \%$ in 2004 , poverty rate decreased from $52.4 \%$ in 1970 to $3.6 \%$ in 2007. At the level of international competitiveness, Malaysian economy maintained a steady improvement moving from $40^{\text {th }}$ in 1980 to $21^{\text {st }}$ position in 2008 in terms of global industrial performance/competitiveness ranking. A projection of poverty rate for 2010 was $2.8 \%$, which was done recently by Economic Planning Unit of Prime Minister's Department.

\section{INDUSTRIALIZATION AND EXPORT PROCESSING ZONE SCHEME IN BANGLADESH}

Bangladesh is a labor abundant but basically a resource constraint developing country with agriculture as the foundation of its economy. Accordingly its development strategy is primarily based on rural and agricultural development. Large and capital intensive industries are pursued through state owned enterprises (SOE). Small scale and cottage industries are promoted through Bangladesh Small and Cottage Industries Corporation (BSCIC). Export-led industrialization is primarily pursued through foreign investment under the Export Processing Zone scheme supervised by Bangladesh EPZ Authority (BEPZA). 


\section{Export Processing Zone Scheme}

In Bangladesh, economic zones are called Export Processing Zones (EPZs). An EPZ here is described as a territory or a stand-alone economic enclave in which goods may be imported and manufactured and reshipped with a reduction in duties and taxes and/or minimal intervention by the custom officials. It is an area where potential investors would find a congenial investment climate with custom and tax incentives and simplified dealing and handling procedures. Its primary objectives are to attract foreign (as well as local) investments, create employment, increase and diversify exports, increase foreign exchange earnings, and stimulate export-led economic growth. The scheme was introduced in 1980s. There are now 8 operating public and 1 recently established private EPZs in Bangladesh. These are spread in the country. In the year 2008/9 they housed about 283 industrial enterprises of which $75 \%$ were entirely foreign owned, $10 \%$ were jointly owned, and the remaining $15 \%$ were entirely locally owned.

EPZs are managed by the Bangladesh Export Processing Zones Authority. Their primary tasks are:

(1) To provide special areas where potential investors would find a congenial investment climate free from cumbersome procedures; and

(2) To provide fiscal and non-fiscal incentives \& facilities like easy custom facilities and tax exemptions, repatriation of full capital and dividend, guarantee of safety of investment through various international insurance programs, and assurance of uninterrupted labor supply with minimum monthly wages ranging from $\$ 30$-60 based on level of skill, etc.

\section{Achievements}

Achievements of EPZ scheme in Bangladesh are very modest. In 2008/9 (Compiled from BEPZA 2011) it provided 234,000 jobs ( $0.43 \%$ of national total employment), accounted for $\$ 2,581.7$ million exports (16\% of national total export), accounted for $\$ 1,582.47$ million investment, and attracted a meager amount of slightly over \$1billion FDI. However, it has been the major source of the increase and diversification of the national exports. EPZs in Bangladesh are stand-alone enclaves with no or least linkages (integration) with the national economy. As a result, they have very modest impact on the economy. However, recently some reforms have been initiated to encourage and facilitate setting up of privately owned zones and backward and forward linkages of the zones with the national economy.

\section{SHORTCOMINGS AND POLICY GUIDELINES FOR REFORM}

In spite of the lowest labor cost Bangladesh has failed to attract any reasonable amount of FDI to expand her EPZ scheme. She greatly failed to gain the confidence of the investors. This is mainly because of perceived poor investment climate arising out of inadequacy and uncertainty of power and water supply, poor roads and transportation infrastructure, lack of security, industrial unrest, political agitations, wrangling and instability, and, above all, lack of full and firm political will \& commitment, and wide spread political and administrative corruptions. Papanek (2010) points out that Bangladesh has the potential to get growth rate of 8-10\% and create 3-4 million jobs a year if she takes advantage of her assets and opportunities. The crucial requirement is investment of $\$ 10$ billion FDI a year. At the moment, Bangladesh is one of the most fortunate countries in the world to have the largest percentage of work-age population of youths which is an essential factor for fast economic 
growth. On the other hand, many multinational corporations (MCs) are aggressively looking for opportunities for investment in low labor cost regions. Therefore, by attracting these Greenfield investors in the country through the EPZ scheme, Bangladesh now has the golden opportunity for industrialization and creation of productive employment for her youthful labor force. She has a great scope to borrow a leaf from Malaysia's smartly designed and managed Economic Zone Model to gear and remodel her EPZ scheme to achieve this goal. Following Malaysia's rich experience, the restructure and reform of the scheme should be based fundamentally on the following crucial aspects : a) firm political will and commitment, b) firm political and administrative discipline (absence of corruption), c) forward and backward linkages of the zones with the rest of the economy, d) mix of public and private owned, and Public-Private owned EPZs, e) fast decision making process by the EPZ authorities, f) uninterrupted abundant supply of cheap and quality labor and absence of labor movement, industrial strikes, political agitation and shutdowns, and g) assured supply of quality physical infrastructure including transportation, communication, electricity, gas, and water.

\section{CONCLUSIONS}

Export Processing Zone (EPZ) is an innovative mechanism primarily aimed at motivating the capital owners from the industrialized countries for Greenfield investment in the developing countries. Coming from a colonial and agrarian background, Malaysia has become one of the most successful nations in benefiting from EPZ scheme as a tool for industrialization. However, EPZ scheme is not a magic wand for industrialization and economic development. Based on the experience of Malaysia and some other successful nations it is clear that for its success there is need for national political will \& commitment, a dynamic structure linking it with the entire economy, and a dedicated and uncorrupted management. EPZ scheme of Bangladesh largely lacks in these requirements. That is why her EPZ could achieve only a modest success. It needs reform and restructuring. Having a similar colonial and agrarian background with Malaysia, Bangladesh has a great scope to emulate Malaysia's most successful economic zone model for the purpose of making her EPZ scheme more dynamic and efficient for greater achievements in the industrialization process of the country. Accordingly a policy guideline for the reform has been suggested in the paper. However, for a more comprehensive policy prescription it may be necessary to study the experiences of some other EPZ applying successful countries like Singapore and China.

\section{REFERENCES}

BEPZA (2011), Website accessed June 24, 2011, from www.epzbangladesh.org.bd BERNAMA (2009), "Cost Of PKFZ Project May Balloon To RM12.453 Bln.” May 28. Accessed June 24, 2011, from http://maritime.bernama.com/news.php?id=414380\&lang=en

Cheng, M.Y. (2008), "Malaysia: Moving towards Vision 2020”. ACI Working Paper Series, Lee Kuan Yew School of Public Policy, National University of Singapore.

ILO (2003), "Employment and social policy in respect of export processing zones (EPZs)", Papers of the Governing Body. 286th Session, March. Accessed June 24, 2011, from http://www.ilo.org/public/libdoc/ilo/GB/286/GB.286_esp_3_engl.pdf

Lim, K., Hamid, J. (2008), "Malaysia faces hurdles on big economic zone". New York Times, June 2. Accessed June 24, 2011, from 
http://www.nytimes.com/2008/06/02/business/worldbusiness/02iht-

rtrinvest03.1.13382290.html

Papanek, G.F. (2010), "Bangladesh Labor Force and Foreign Private Investment Major Asset or Biggest Problem", a talk at Dhaka, Bangladesh, April 2010, Boston Institute for Developing Economics (BIDE), USA.

PRU (Public Relations Unit) (2011), Free Zone Procedure, Royal Customs and Excise Headquarters, Kuala Lumpur, Malaysia. Accessed June 24, 2011, from http://www.portsworld.com/customs/proc_freezone.htm

Raquib, M.A., Murad, M.W., Molla, R.I. (2007), "Going Global: A Strategy for Acquiring Managerial Capabilities for Sustainable Development in Developing Countries", Presented at the $14^{\text {th }}$ Annual International Conference on Advances in Management, July 1827, Ontario, Canada.

US State Department (2011) "Investment Climate Statement - Malaysia, Bureau of Economic, Energy and Business Affairs", March. Accessed June 24, 2011, from http://www.state.gov/e/eeb/rls/othr/ics/2011/157318.htm

WTEC (1997), "Malaysia", May. Accessed June 24, 2011, from

http://www.wtec.org/loyola/em/04_07.htm 